\title{
Bacterial resistance in intensive care units: a review
}

\author{
Camila Gomes Teotônio da Silva ${ }^{1 *}$; Larissa Rozalina Cavalcanti do Nascimento ${ }^{2}$; Maria Luisa Souza \\ Vilar $^{3}$; Beatriz Alessandra de Moura Alves ${ }^{4}$; Ione Teresinha Oliveira Leitão ${ }^{5}$; Bráulio Wagner \\ Correia da Silva ${ }^{6}$; Brunna Karolline Carvalho de Vasconcelos ${ }^{7}$; Kayllane Beatriz Tenório da Silva \\ Letícia Andressa de Souza Moura ${ }^{9}$; Luana dos Santos Silva ${ }^{10}$; Milena Silva de Medeiros ${ }^{11}$; Edson \\ André Batista ${ }^{12}$; José Lucas da Silva Moura ${ }^{13}$
}

1 - 4 Bachelor's degree in Biomedicine from the University Center of Vitória de Santo Antão - UNIVISA.

5 Master's degree in education from the Ibero-American University Foundation - FUNIBER.

6 Undergraduate in Pharmacy from the University Center of Vitória de Santo Antão - UNIVISA.

7 - 12 Bachelor's degree in Pharmacy from the University Center of Vitória de Santo Antão - UNIVISA.

.13 Bachelor's degree in Nursing from the University Center of Vitória de Santo Antão - UNIVISA.

E-mail adresses: camilagomesgt63@gmail.com (Camila Gomes Teotônio da Silva), larissarozalinaa1994@gmail.com (Larissa Rozalina Cavalcanti do Nascimento), marialuisaa0350@gmail.com (Maria Luisa Souza Vilar), (Beatriz Alessandra de Moura Alves), ione.teresinhal@gmail.com (Ione Teresinha Oliveira Leitão), brauliowagner2506@gmail.com (Bráulio Wagner Correia da Silva), brunnakarolline85@gmail.com (Brunna Karolline Carvalho de Vasconcelos), kayllanebeatriz224@gmail.com (Kayllane Beatriz Tenório da Silva), leticiamouraa6@gmail.com (Letícia Andressa de Souza Moura), lluanna.santossilva@gmail.com (Luana dos Santos Silva), milena.medeiros1@outlook.com (Milena Silva de Medeiros), edsonandre.pe@gmail.com (Edson André Batista), mouraluccas@yahoo.com.br (José Lucas da Silva Moura).

${ }^{*}$ Corresponding author

\section{To cite this article:}

Silva, C.G.T.; Nascimento, L.R.C.; Vilar, M.L.S.; Alves, B.A.M.; Leitão, I.T.O.; Silva, B.W.C.; Vasconcelos, B.K.C.; Silva, K.B.T.; Moura, L.A.S.; Silva, L.S.; Medeiros, M.S.; Batista, E.A.; Moura, J.L.S. Bacterial resistance in intensive care units: a review. International Journal of Sciences. Vol. 2, No. 3, 2021, pp. 71-75. ISSN 2763-5392.

Received: 10 15, 2021; Accepted: 10 16, 2021; Published: 11 03, 2021

\begin{abstract}
Hospital infections (HI) are related to hospitalization and can be defined when the incubation period of the pathogen causing the infection is unknown and there is no clinical evidence or laboratory data of infection at the time of hospitalization or after 72 hours of hospital admission of the patient. Thus, this research aims to demonstrate the main bacterial resistance strains against antimicrobials in the ICU environment. A narrative literature review was conducted for retrospective observational study. The literary findings demonstrated that there is a diversity in pharmacological treatment, however with the indiscriminate use of these bacteria have naturally gained resistances, especially in the ICU. Epidemiological data showed that the percentage of these resistances are high and that they can bring expenses of very high people with money for the health of the affected population. This requires more elaborate interventions to prevent and control such infections within the ICU.
\end{abstract}

Keywords: Bacterial pharmaco-resistance; Hospital Infection; Therapeutic Measures.

\section{Introduction}

Considered as an immense reservoir of virulent and opportunistic pathogens, the hospital environment has a vast probability of causing a profile of infections through bacteria and viruses to which they are part of this scenario. These infections play an important role in patient care, because without proper precautions and care, these patients can acquire such infections and may even die. Among the infections that affect hospitalized individuals, infections of the bloodstream, urinary tract, respiratory tract and postoperative wounds are those that occur most frequently (GRILO, et al, 2013).

Hospital infections (HI) are related to hospitalization and can be defined when the incubation period of the pathogen causing the infection is unknown and there is no clinical evidence or laboratory data infection at the time of hospitalization or 72 hours after the patient's hospital admission (MINISTERIO DA SAUDE, 2005). The profile 
of these infections where they are considered a world health problem is a contributing factor to increased morbidity, lethality, increased hospital stays of patients, increased hospital costs and the spread of bacteria antimicrobial resistant (MEDEIROS, 2010).

Among the hospital units, the intensive care unit (ICU) represents a timely environment for the presence of pathogens. Several internal and external factors contribute to the presence of microorganisms in the ICU, such as the diversity and dissemination of these agents caused by the flow of patients undergoing surgery, long hospital stay, underlying disease, use of urinary and venous catheters, mechanical ventilation and immunological status leaving patients more likely to acquire infections. In addition, the use of medications, such as antibiotics, can contribute to a high rate of antimicrobial resistance, hindering the treatment of the patient, causing greater complications (ARCANJO, 2017).

Due to the fact that patients have already developed high resistance to virtually all available antimicrobials, it makes bacterial resistance to antimicrobials the main problem in ICUs, generating serious consequences due to the lack of therapeutic option for the treatment of infections caused by microorganisms (PAIM; LORENZINI, 2014).

The present work aims to demonstrate the main bacterial resistance against antimicrobials in the ICU environment.

\section{Methodology}

A narrative literature review was conducted for retrospective observational study. As a first stage, a bibliographic survey was made in order to obtain all the references found on the theme addressed. The references used were websites, scientific articles, dissertations and doctoral theses described in lilacs, PubMed., SciELO and Periodicals Portal CAPES, Science Direct. The health descriptors used in Health Sciences (DeCs) were: "Gram-Negative Aerobic Bacteria"; "hospital infection", "Pharmacoresistance", "Gram-Negative Aerobic Bacteria", "Cross Infection", "Drug Resistance". The literature consulted was published from 2000 to 2020, using as inclusion criteria studies in Portuguese and English and some studies with a date prior to the publication period.

Therefore, studies that did not meet these criteria were excluded. From this survey, we contextualized the problem and the analysis of the possibilities present in the literature consulted for the conception of the theoretical framework of the research. From this survey, a narrative review was elaborated to establish relationships with previous scientific productions, identify recurrent themes and point out new perspectives, aiming at the construction of an updated work.

\section{Results and Discussion}

\subsection{Antimicrobials and their mechanisms}

Antibiotics are a class of drugs used for the treatment of infectious pathologies that differ from each other regarding their pharmacological, physical, chemical properties in the spectrum and mechanism of action. Discovered in the midtwentieth century, it has a primary function in this treatment, however for antibiotic therapy to be effective, there are important criteria that must be taken into consideration, such as the imperative that there is a target (linker) within the bacterial cell and that there is a sufficient concentration of drugs for the action (PAIM; LORENZINI, 2014).

In order to obtain the ideal treatment in relation to antibiotics, the literature studied showed that according to Menezes et al. (2015), the drug should have the selective target, which had a rapid bactericidal action, narrow spectrum of action that does not interfere in the saprophyte microbiota, with the lowest toxic level and high therapeutic levels, besides having few adverse reactions, diversity of pathways for administration, good distribution in infection and not contradicting the normal immune defenses of the host, resistance and be cost-effective. However, all these characteristics are difficult to achieve.

Over time several antibiotics have been discovered in order to demonstrate the advancement in science and technology as well as bring new therapeutic approaches for this process, however with the indiscriminate use and the super speed at which bacteria become resistant this process ends up being quite slow and challenging. According to Santos, Nogueira and Mendonça (2015), Marquioti, Janes and Castro (2015) and Quesada et al. (2016), antimicrobials are separated according to their chemical structures and mechanisms of action belonging, therefore, there are different classes such as: antibiotics inhibitors of cell wall synthesis (Penicillin, Cephalosporins, Carbapenems, Monobactamicosee the Glycopeptides), the antibiotics that inhibit the synthesis of purines and folic acid (Trimetropine and sulfonamides), those acting on the cytoplasmic membrane (Polymyxin B), antibiotics that inhibit synthesis protein (30S=Tetracyclines, aminoglycosides, $50 \mathrm{~s}=$ Macrolides, Chloramphenicol, lincosamines) and finally DNA synthesis inhibitors (Quinolones).

In addition to these, there are also those antibiotics that do not fit any of the classifications mentioned, as is the case of Etambutol, with use in the treatment of tuberculosis and has action through inhibition of the formation of the cell wall of bacteria (SANTOS; WALNUT; MENDONÇA, 2015).

\subsection{Bacterial resistance to antimicrobials}

Bacteria are classified as microorganisms are prokaryote and without karyotheca, and all have cytoplasm, ribosomes, a plasma membrane and a nucleoid (KOONIN, 2014). Invisible to the naked eye, they have a variable size depending on the species 0.2 to $1.5 \mu \mathrm{m}$ in length, and bacteria of medical importance have an average size between 0.5 to $1.0 \mu \mathrm{m}$ by 2 to $5 \mu \mathrm{m}$. Based on the structure of their cell wall, they can be classified as: Gram-positive and Gram negative (CARVALHO, 2010). In Gram-positive, the cell wall consists of about $75 \%$ peptidoglycan, corresponding to a thicker layer. The remainder is composed of other proteins and telic acid, which is divided into two types: wall telic acids bound to peptidoglycan and lipoprotein acids (LTA) (MURRAY, 2017). 
In gram-negative bacteria, the cell wall is more complex and does not have the telic acid, has a much slender layer of peptidoglycan and has an external membrane that consists of a double lipid layer, in which the periplasmic space divides these two components (MENEZES, 2015).

As a way to suit the environment, several bacteria create their own means of survival and adaptation through numerous mechanisms of resistance against actions of the various antibiotics. The literature studied demonstrates that there is a classification for this type of process, this classification can be given in four basic ways: by preventing the action of the antibiotic on its target; by antibiotic modification, alteration of the primary binding site; and the production of an alternative target resistant to the inhibiting action of the chemical agent However, the mechanism of antibiotic modification is the most common thanks to the actions of enzymatic reactions, such as ox reduction and horizontal transfer of genes, where the bacterium manages to maintain the same sensitive target but the drug cannot reach it (TANWAR,2016).

However, resistant bacteria, for their instead, they can act protecting the target from antibiotic action, by rapid pumping to the extracellular medium or even inducing the intake block age of the drug into the cell, preventing the action of the drug. In change in the primary binding site, the antibiotic is unable to act on its target due to structural change of that site. Finally, there are strains capable of producing alternative targets, resistant to the action of the antibiotic, i.e., a metabolic pathway is created that by turns the action of (LIU et al., 2020). Because of these causes is that bacterial resistance becomes a problem from health Publishes where makes up important a discussion in character Multidisciplinary towards one greater number of action strategies, from the nature of infectious diseases, as well as pharmacotherapeutic methods in force and also included environmental factors, relevant to the issue (ROWLANDS et al., 2014). Table 1 Demonstrates the Main Strains Resistant an antibiotic than healthy Found so much in hospital environment as well as in unit from intensive care.

Table 1. Main bacteria mentioned by the WHO (World Health Organization) with a high rate of hospital bacterial resistance.

\begin{tabular}{|c|c|c|c|}
\hline Microorganism & $\begin{array}{l}\text { Mechanism of } \\
\text { resistance }\end{array}$ & $\begin{array}{c}\text { Antimicrobials } \\
\text { Resistant }\end{array}$ & Authors \\
\hline Klebsiella spp. & $\begin{array}{l}\text { The main mechanism of } \\
\text { resistance of this } \\
\text { bacterium is the } \\
\text { production of the beta- } \\
\text { lactamase enzyme, which } \\
\text { is encoded by plasmids } \\
\text { and transmitted to } \\
\text { descendants after the } \\
\text { reproduction processes }\end{array}$ & $\begin{array}{c}\text { Class of } \\
\text { Betalactamics } \\
\text { such as } \\
\text { cephalosporins, } \\
\text { penicillin's, } \\
\text { monobactams } \\
\text { and } \\
\text { carbapenems }\end{array}$ & $\begin{array}{c}\text { Chen et al., } \\
2020 \text {; } \\
\text { Tanwar et al., } \\
2014 .\end{array}$ \\
\hline
\end{tabular}

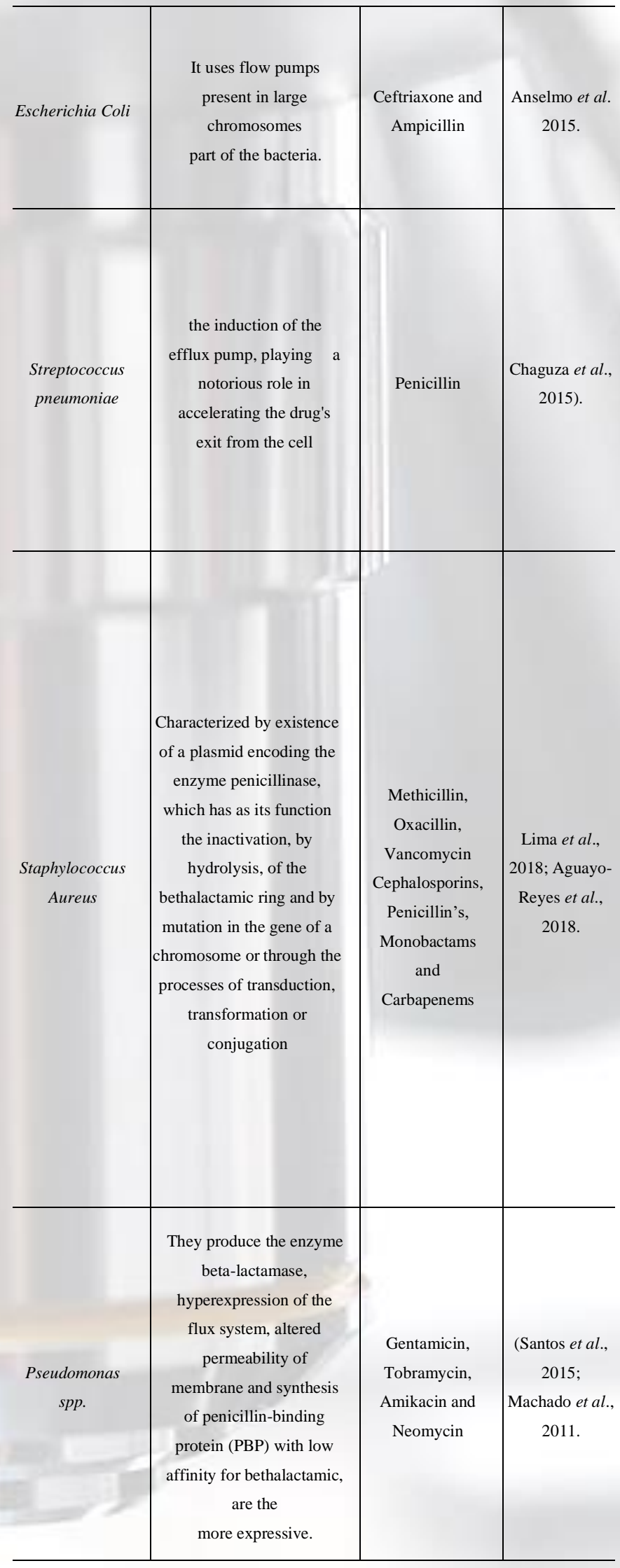

Prepared by: Authors, 2021 
4 Silva, C.G.T.; Nascimento, L.R.C.; Vilar, M.L.S.; Alves, B.A.M.; Leitão, I.T.O.; Silva, B.W.C.; Vasconcelos, B.K.C.; Silva, K.B.T.; Moura, L.A.S.; Silva, L.S.; Medeiros, M.S.; Batista, E.A.; Moura, J.L.S. Bacterial resistance in intensive care units: a review...

The indiscriminate use of antibiotics is a primary factor for bacterial resistance to this type of medication. With its increasingly refined resistance mechanisms it is very likely to control this type of infections within hospitals. The researched literature showed that an epidemiological survey of the microbial profile was conducted in an intensive care unit with 98 patients, the most prevalent bacteria were $P$. aeruginosa, $E$. coli and $K$. pneumoniae, totaling almost half of the infections (Basso et al., 2016; Lima, 2018). However, in another site a survey was made in swab samples at the time of hospitalization and it was evidenced that of the $66 \%$ of the samples collected at the time of hospitalization, it was positive for $P$ auruginosa which reached the top of the list in a retrospective and cross-sectional study (BERTÃO et al., 2018; MOTA et al., 2018).

In addition to the indiscriminate use of antimicrobials, several factors may be associated with this epidemiological issue of bacterial resistance, because North American studies report that up to $50 \%$ of ICU infections are associated with the use of invasive devices, and have as etiological agents resistant microorganisms, being Acinetobacter sp., Pseudomonas sp., Klebsiella sp., Methicillin-resistant Staphylococcus aureus (MRSA) and Escherichia coli, often present(DHILLON AND CLARK, 2005). Compared to Brazilian studies conducted in intensive care units, they report an association between the use of vesicle delay probes, central catheters and mechanical ventilation and the increase in infections developed in these units, a situation in which more than $75 \%$ of patients with infections use such procedures. In addition, there is a predominance of resistant agents such as S. Aureus, $P$. aeruginosa and K. pneumoniae (LISBOA et al, 2007).

In addition, bacterial infections with a resistance profile to pharmacological treatment generate high costs due to the length of stay in the unit, as well as the use of combined antibiotics where the purchase price and sometimes additional surgeries are high (PINKNEY et al., 2013). In Brazil, according to ANVISA data from 2013, R\$ 803.59 are spent per day on surgical site infections and $\mathrm{R} \$ 666.47$ on bloodstream infections associated with a catheter. In addition, bacterial resistance aggravates the situation, as it tends to increase over the years, culminating in longer hospitalizations and, consequently, higher expenses.

\section{Conclusions}

As seen in the literature, the bacterial resistance process occurs naturally because they have sufficient mechanisms of action to remain in the environment that are inserted thus generating various disorders and harms to human life, however we cannot fail to observe the external factors that are of great importance for this process, such as the use of antimicrobials in a disoriented and accelerated manner.

Within these perspectives, it is up to health professionals to always reinforce the importance of use and bring new approaches to prevention and care as well as the government's investment in bringing new therapeutic alternatives as a way to contain this medicating advance to bacterial resistance. Furthermore, more and more studies on the profile of susceptibility and microbial prevalence are needed within the ICU's, to design public health strategies aimed at controlling pharmakon resistance aiming at a reduction in cases, as well as the reduction of health care expenses in this context.

\section{References}

[1] AGUAYO-REYES, A. et al. Bases moleculares de la resistencia a meticilina en Staphylococcus aureus. Rev Chilena Infectol. v. 35, n. 1, p, 7-14, 2018.

[2] ANSELMO, D. B.; WERLE, C. H.; HOFFMANN, F. L. Ocorrência de Escherichia coli e Staphylococcus aureus resistentes a antimicrobianos e parasitos Entamoeba coli e Ascaris lumbricoides em merendas escolares. Rev Inst Adolfo Lutz. v. 74, n.4, p. 399-409, 2015.

[3] ARCANJO, R.; Oliveira, A. C. Fatores associados à colonização axilar por microrganismo resistente em pacientes na unidade de terapia intensiva. Rev Aten Saúde. v.15, n.51, p.11- 17,2017.

[4] BERTÃO, M. V. et al. Estirpes Produtoras de BetaLactamases de Espectro Alargado: A Realidade num Hospital Central. Medicina Interna. v. 25, n. 3, p. 179$185,2018$.

[5] CARVAlHO, I. T. e-Tec Brasil. Microbiologia Básica. Universidade federal rural de Pernambuco (UFRPE), Colégio Agrícola Dom Agostinho Ikas (CODAI), Universidade do Rio Grande do Norte (UFRN). Recife: EDUFRPE, 2010.

[6] CHAGuZA, C.; CORNICK, J. E.; EVERETT, D. B. Mechanisms and impact of genetic recombination in the evolution of Streptococcus pneumoniae. Comput Struct Biotechnol J. v. 13, p. 241-247, 2015.

[7] CHEN, D. et al. Characterization of carbapenemresistant Klebsiella pneumoniae in a tertiary hospital in Fuzhou, China. Journal of Applied Microbiology. v.129, n. 5, p. 1220-1226, 2020.

[8] DHILLON, R.; Clark, J. Infection in the intensive care unit (ICU). Curr Anaesth Crit Care. 2009; v. 20 n.4, p. 175-82, 2009.

[9] GRILLO, V.T.R.S. et al. Incidência bacteriana e perfil de resistência a antimicrobianos em pacientes pediátricos de um hospital público de Rondônia, Brasil. Rev Ciênc Farm Bás Apl. v. 34, n. 1, p.117-23, 2013.

[10] KOONIN, E. V. Carl Woese's vision of cellular evolution and the domains of life. RNA Biology, v.11, n. 3, p. 197204, 2014.

[11] LIMA, V. S. Avaliação das culturas de vigilância em pacientes sob risco de colonização por bactérias multirresistentes à admissão hospitalar (Monografia). [Aracaju]: Universidade Federal do Sergipe. p. 51. 2018.

[12] LISBOA T. et. al. Prevalência de infecção nosocomial em unidades de terapia intensiva no Rio Grande do Sul. Rev Bras Ter Intens. v. 19, n. 4, p. 414-20,2007. 
[13] LIU, M. et al. Antimicrobial Resistance and Molecular Characterization of Gene Cassettes from Class 1 Integrons in Pseudomonas aeruginosa Strains. Microb Drug Resist. 2020.

[14] MACHADO, G. M. et al. Occurrence and the susceptibility to antimicrobial agents in Pseudomonas aeruginosa and Acinetobacter sp. at a tertiary hospital in southern Brazil. Rev. Soc. Bras. Med. Trop. v. 44, n. 2, p. 168-172,2011.

[15] MARQUIOTI, C. M. J.; LANES. L. C.; CASTRO, G. F. P. Uso irracional de antibióticos na infância: contribuição do profissional farmacêutico para a promoção da saúde.

[16] Revista Transformar, Rio de Janeiro, $7^{\circ}$ edição. p. 17993, 2015.

[17] MEDEIROS, E.A.S.; Rosenthal, C. A prática segura e a qualidade na atenção In: $O$ controle da infecção hospitalar no Estado de São Paulo. São Paulo: Conselho Regional de Medicina do Estado de São Paulo, 2010.

[18] MENEZES, R. P. et al. Frequency of candida species in a tertiary care hospital in triangulo mineiro, Minas Gerais State, Brazil. Revista do Instituto de Medicina Tropical. São Paulo, v. 57, n. 3, p. 185-191, 2015.

[19] Ministério da Saúde (Br). Agência Nacional de Vigilância Sanitária. Pediatria: prevenção e controle de infecção hospitalar. Brasília (DF): ANVISA; 2005.

[20] MOTA, F. S., Oliveira, H. A. \& Souto, R. C. F. Perfil e prevalência de resistência aos antimicrobianos de bactérias Gram-negativas isoladas de pacientes de uma unidade de terapia intensiva. RBAC. V. 50 , n.3, p. 270-7, 2018.

[21] MURRAY, P. R; ROSENTHAL, K. S; PFALLER, M. A. Microbiologia Médica. Tradução da $7^{\mathrm{a}}$ Edição. Saunders Elsevier. 2014.

[22] PAIM, R. S. P.; LORENZINI, E. Estratégia para prevenção de resistência bacteriana: contribuição para a segurança do paciente. Revista Cuidarte, Colômbia, v. 5, n. 2, p. 757- 64, 2014.

[23] PINKNEY, Thomas D. et al. Impacto dos dispositivos de proteção da borda da ferida na infecção do sítio cirúrgico após laparotomia: ensaio clínico randomizado multicêntrico (ROSSINI Trial). Bmj, v. 347, 2013.

[24] QUESADA, A. et al. Resistencia antimicrobiana de Salmonella spp isolada de alimentos de origem animal para Consumo humano. Revista Peruana de Medicina Experimental e Saúde Pública, Peru, v. 33, n. 1, p. 32-44, 2016.

[25] ROWLANDS, R. E. G. et al. Prevalence of drug resistance and virulence features in Salmonella spp. isolated from foods associated or not with salmonellosis in Brazil. Revista do Instituto de Medicina Tropical Sao Paulo, v. 56, n. 6, p. 461-467, 2014.

[26] SANTOS, I. A. L.; NOGUEIRA, J. M. R; MENDONÇA, F. C. R. Mecanismos de

[27] resistência antimicrobiana em Pseudomonas aeruginosa. Revista Brasileira de Análises Clínicas, Rio de Janeiro, v. 47, n. 1-2, p. 5-12, 2015.
[28] TANWAR, J. et al. Resistência a múltiplas drogas: uma crise emergente. Perspectivas interdisciplinares sobre doenças infecciosas, v. 2014, 2014. 